\title{
Unveiling the professional attributes of university teachers
}

\author{
Rubby Dhunpath ${ }^{1 \#}$, Lynn Biggs ${ }^{2}$, Hanlie Dippenaar ${ }^{3}$, Hesta Friedrich-Nel ${ }^{4}$, Deidre Joubert ${ }^{5}$, Ian \\ Nell $^{6}$, and Jacqueline Yeats ${ }^{7}$ \\ ${ }^{1}$ University of Kwa-Zulu Natal \\ ${ }^{2}$ Mandela University \\ ${ }^{3}$ Cape Peninsula University of Technology \\ ${ }^{4}$ Central University of Technology \\ ${ }^{5}$ Vaal University of Technology \\ ${ }^{6}$ University of Stellenbosch \\ 'University of Cape Town \\ "Corresponding Author: Dhunpath@ukzn.ac.za
}

(Submitted: 29 September 2020; Accepted: 9 September 2021)

\begin{abstract}
This article derives from a collaborative higher education project, conceptualised, and implemented by academics from seven South African universities. These academics are members of the South African Teaching Advancement at University (TAU) Fellowship. The project has its roots in the Department of Higher Education's National Framework for Enhancing Academics as University Teachers, which identifies six leverage points or 'imperatives for action', one of which is the imperative to develop expectations (attributes) of academics in their role as university teachers. TAU Fellows engaged in the collaborative enquiry over a period of three years, appropriating a conceptual framework posited by Henry Giroux, of teachers as transformative intellectuals. In this article, each author reflects on his/her own scholarship of teaching and learning (SoTL) endeavours, which provided the conceptual tools to illuminate what for them and the group, are valuable professional attributes. The metaphor of the Baobab tree is appropriated to signify 'rhizomatic thinking', which portrays teaching as subconscious, subversive, non-linear, multi-directional, serendipitous, esoteric, dynamic, unbounded, unpredictable, adaptive, and non-hierarchical. This SoTL enquiry enabled the TAU group to unveil and declare their professional attributes as they made public their praxis. The attributes include academics as imbued with the capacity for critical thinking and actively promoting critical thinking amongst their students; as active learning mediators; as responsive, innovative, and relevant curriculum designers; and as engaged professionals. Appreciation of the article is enhanced when the reader first views this video https://youtu.be/yoAgguMut-8.
\end{abstract}

Keywords: critical thinking, higher education transformation, professional attributes, rhizomatic thinking, SoTL, university teachers 


\section{Introduction}

In 2018, the Department of Higher Education (DHET) published a National Framework for Enhancing Academics as University Teachers (DHET, 2018:3), which identifies six leverage points or 'imperatives for action', to 'create structural, systemic ways to improve the quality of university teaching and thus, student success'. The Framework aims to coordinate the development of academics as university teachers by identifying imperatives which include continuous professional development for university teachers; establishing teacher development structures; organisations and resources, ensuring recognition and awards for academics as university teachers; leadership development of academics; and knowledge production and sharing about university teaching and learning.

Acknowledging that current higher education development activities and resources are unequally dispersed, the DHET Framework envisions providing 'a stable, long-term base for

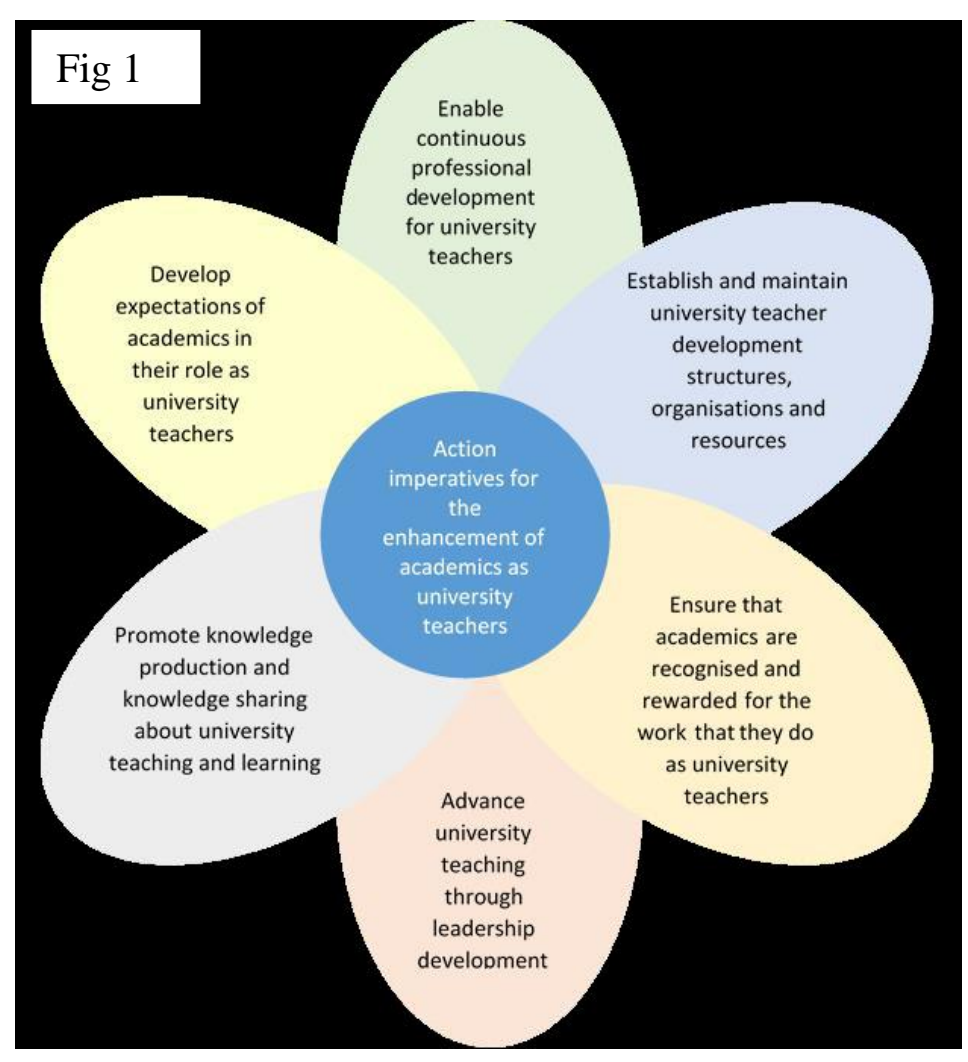
national initiatives and raises the status of university teachers and teaching' (ibid. 3).

The authors of this article contend that a crucial precondition to defining the long-term development agenda propounded in the DHET Framework, is the imperative to articulate understandings of what attributes (expectations) are deemed valuable in our commitment to 'nurturing, supporting, and developing academics as university teachers' (4). To this end, the authors, all members of the Teaching Advancement at Universities (TAU) Fellowship ${ }^{1}$ and their Advisor, embarked on a project which enabled them to interrogate their own practices to determine what constitutes valuable attributes of an academic as university teacher.

This collaborative project was, in the first instance, activated with the declared aim by the group of seven academics, from different disciplines, to identify valuable attributes of their students. As consensus emerged on valued graduate attributes, it became increasingly apparent that an urgent pre-condition was to identify what professional attributes academics needed to be imbued with, to activate those valued attributes amongst their students. This nexus was

\footnotetext{
${ }^{1}$ See https://heltasa.org.za/tau/: The Teaching Advancement at Universities (TAU) Fellowship is a national initiative designed to recruit and promote a group of higher education professionals as change agents.
} 
represented metaphorically using the botanic image of the baobab tree ${ }^{2}$. The emerging expectations and attributes drew on the authors' own lived experiences captured in their individual teaching practices in their own institutions and resonated with the ideas of Henry Giroux of teachers as transformative intellectuals (Giroux, 1988). We realise that increasingly, professions are demanding more than academic/technical competence from graduates. What is increasingly deemed valuable, are attributes such as creativity, innovation, problem-solving and critical thinking. Thus, over the course of the Fellowship engagements, the theme of critical thinking dominated conversations and formal discussions.

Acknowledging that critical thinking remains a 'fuzzy' concept in higher education and that the academy does not have boundless freedom to transgress the knowledge regimes prescribed by the disciplines and professions, we adopted a less relativist position, conceding the existence of 'academic tribes', with their epistemic cultures and prescripts (Trowler, 2005). A key professional attribute is indeed the ability to recognise these prescripts; that they are bound by rules and values about what constitutes knowledge in the disciplines and how these can be known and codified as legitimate knowledge. We acknowledged also, that while knowledge construction takes place in structured domains, our existence is multifaceted, like the rhizomatic metaphor of the Baobab tree, which demands an appreciation of complexity and diversity, if academics are to be transformative intellectuals.

The Baobab tree, with its rhizome-like roots, represents the rhizomatic patterns of engagement between academics, students, and the environment. There is no beginning and no end to this complex and intricate ecosystem, relentlessly generative (of new knowledge), while the shoots and branches are spontaneous, organic, and unpredictable - as is the nature of knowledge generation. The roots buried deep in the African soil, anchor and feed the valued graduate attributes represented by the leaves and fruit of the tree (see Figure 2).

Rhizomatic intelligence is a way of thinking about learning, as advanced by Deleuze and Guattari in A Thousand Plateaus (1987). This learning philosophy posits that ideas, like the stem of a rhizomatic plant, send out roots and shoots as they spread, connecting multifariously, while reducible to neither the one nor the multiple. The growth and the connections made during the learning process are organic, spontaneous, and unpredictable, yet are all inextricably bound to one another as part of a much larger framework or growth system. Hence, like the learning process itself, a rhizome (sometimes called a creeping rootstalk) has no beginning and no end. It is comprised not of units but of dimensions, that are always detachable, connectable, reversible, modifiable and have multiple entranceways and exits and its own lines of flight (see Deleuze \& Guattari, 1987:21). This, for the group, represented the qualities of the organic intellectual.

\footnotetext{
${ }^{2}$ See the electronic poster here https://youtu.be/yoA9guMut-8 which represents the diversity of professional and academic attributes.
} 


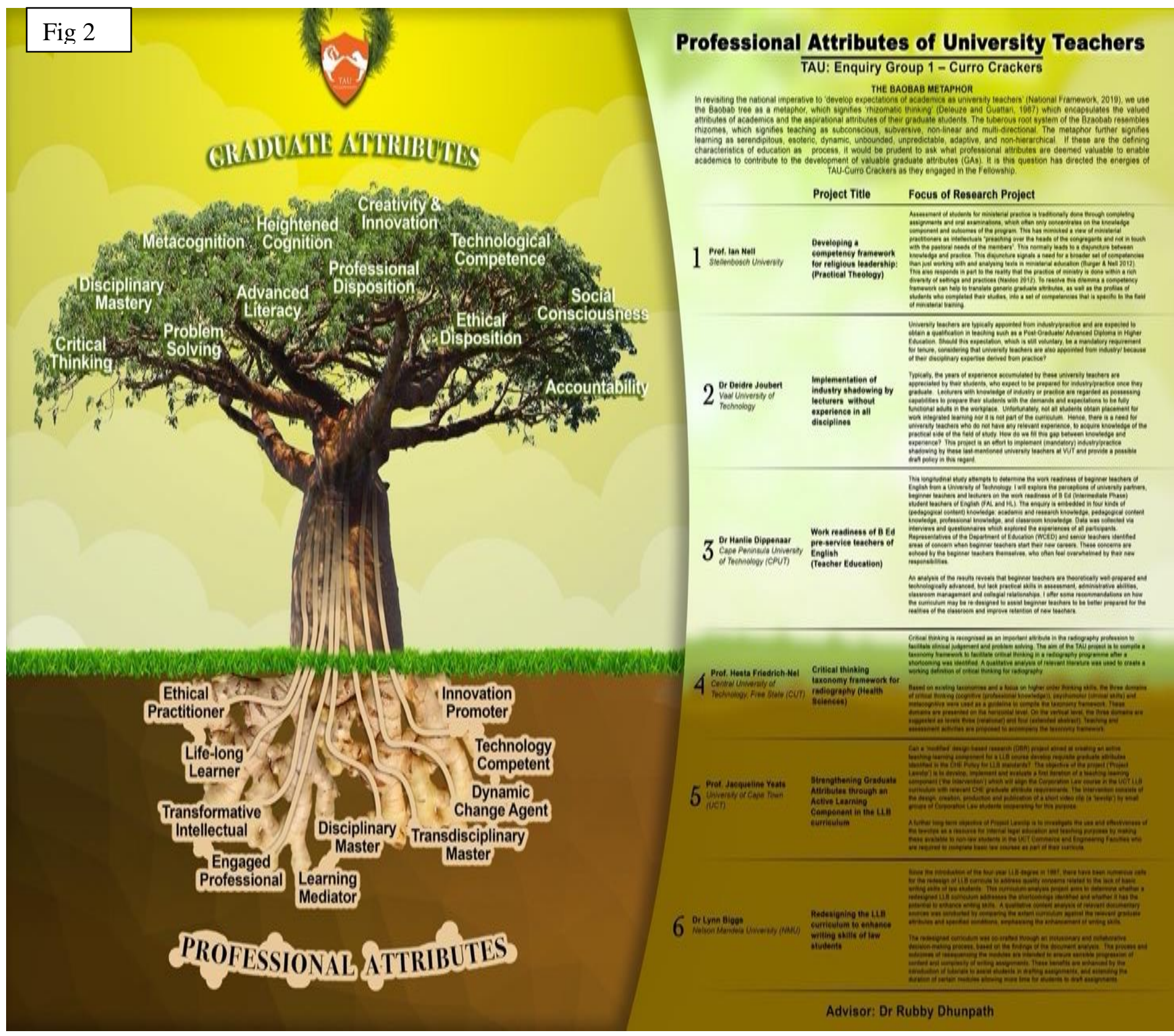

Figure 2: Baobab image

The nurturing environment in which the Baobab tree thrives, is also subject to environmental factors caused by extreme weather patterns, water scarcity and turbulent winds. This can be aligned with the current turbulent, diverse, and unequal South African higher education context reflected in the diverse student population, their learning needs, prior knowledge, and social and cultural contexts. Socio-cultural learning theories emphasise the teachers' influence and role to enable epistemological access, scaffold learning, shape students' attitudes and behaviour, develop problem solving and introduce the student to academic discourses (Northedge, 2003). The teacher models, helps to make connections, demonstrates, and collaborates (Harland, 2003). Mezirow (2009) illustrates the transformative ability of learning 
through critical reflection and reflective practice. Responding to the transformative higher education environment, university teachers and students need to collaborate actively in this process and participate in the metamorphosis, with critical thinking identified as a core attribute.

In this article, we pursue three outcomes: Firstly, we provide theoretical perspectives which enabled us to engage in our individual and collective explorations, particularly the notion of the academic as a transformational intellectual as advanced by Freire (2000) and Giroux (1988). Our adoption of the Baobab metaphor provided the conceptual lens to interrogate what we deem valuable professional attributes. Secondly, we put up for scrutiny, our individual Scholarship of Teaching and Learning (SoTL) endeavours, expressed in our individual TAU Fellowship projects as we explored our professional identities and the emergent professional attributes. Finally, we reflect on the Baobab metaphor and how rhizomatic thinking forced us to elevate our states of individual consciousness in defining our valued professional attributes.

\section{Theoretical perspectives}

Our thinking is influenced by the seminal ideas of Freire (2000) and Giroux (1988) which foreground the importance of humanity in education, embedded in culture, class, ethnicity, power, and gender. While these theoretical framings have their roots in general education and schooling, we believe they have explanatory power, especially in availing us with a vocabulary to understand the dialectical relationship between social structure and human agency - key ingredients of an emancipatory scholarship of teaching and learning. Giroux's conceptions of agency emphasise human subjects not as passive victims of ideology and political agendas, but able to transcend the historical inheritance thrust upon them by applying critical knowledge to alter their own destiny and future. Giroux (1992) based his ideas on the work of Foucault and Gordon (1980), who challenge concepts of learners as being passive recipients of ideologies. Instead, they are actively involved in the intellectual dialogue, which resonates with Paulo Freire's ideas on critical pedagogy (Freire, 2000). In the Foucauldian sense, Giroux implies that the concepts of power and meaning should be developed in the mind of the learner in a way that allows the student to critically accept, negotiate, or reject what came its way (Giroux, 1992).

We argue that the push for generic graduate attributes is indeed a reflection of the neoliberal push and vocationalisation of higher education to fulfil the needs of the workplace, finding expression more recently in micro-credentialing of gig qualifications for the gig economy (see Wheelahan and Moodie, 2021). Giroux (1992) cautions against the push towards vocationalising in higher education, and warns that educators should oppose this, as institutions of higher learning are not in service of the consumer-focused corporate world and should not be embedded in a neo-liberal market culture. Giroux (2003) proposes that critical pedagogy in education creates the possibilities for social transformation. He sees critical theory as having a dual purpose which provides a lens to analyse situations and a means to change them. Kincheloe, et al. (2018: ix), describe Giroux as 'prodigious and multidimensional'. They further describe his work as an 'effort to expand the possibility for social justice, freedom, and egalitarian social relations in the educational, economic, political, and cultural domains that locate men, women, 
and children in everyday life' (Kincheloe, et al., 2018: ix), which echoes the conception of the lecturer as a transformative intellectual in the development of students. Giroux's interpretation of teachers (academics) as transformative intellectuals shows his understanding of the role of education in cultivating critical citizens (1992). He argues that

...to rethink and restructure the nature of teacher work is to view teachers as transformative intellectuals...First, [the category of intellectual] provides a theoretical basis for examining teacher work as a form of intellectual labor, as opposed to defining it in purely instrumental or technical terms. Second, it clarifies the kinds of ideological and practical conditions necessary for teachers to function as intellectuals. Third, it helps to make clear the role teachers play in producing and legitimating various political, economic, and social interests through the pedagogies they endorse and utilize (Giroux, 1988: 125).

Aronowitz and Giroux (1993) encourage educators to question the nature of education and how educators should engage around broader educational concerns. Transformative teachers have the power to develop students' critical thinking and reflection, beyond transmission of skills and knowledge. Giroux (2015) infers that the dialogue over education should include not only schools, but also tertiary education as an implied agent of social reform, as has been experienced in South Africa through the rise of various \#Fallist movements. He shows that one cannot talk about education without addressing the political, economic, and social realities in which education is embedded.

We now turn our focus to the role of teaching and learning in catalysing creative thinking. Ashwin, et al. (2015) remind us that learning takes place within specific contexts. On a continuum, the student's prior knowledge, contextual experiences, and how they perceive the teaching and learning context, how they approach their learning, all determine how they experience the learning outcomes and the curriculum. University teachers can contribute to transformative thinking by engaging students in active learning and innovative teaching practices (Giroux, 2015). These concepts trigger the question, what constitutes the curriculum and how the curriculum can transform the teacher and the student.

The transformed academic as university teacher should internalise the responsibility of advancing agency and should apply critical teaching and learning to enhance opportunities for students to be active producers of knowledge (Giroux, et al., in Giroux, 1988; Giroux and McLaren, 1989). While humans are not completely free to generate authentic knowledge, it does not relieve academics of the obligation to purposefully expose them to knowledge, skills, and values that will enable them to produce authentic, new knowledge. When teachers are 'transformative intellectuals', they are enabled to develop critically appropriate curricula to address the cultural and social contexts in which they teach. A transformed teacher is a reflective scholar and practitioner. Teachers who are 'transformative intellectuals' guide students to be critical scholars themselves, imbued with the capacity to critique economic, political, and social injustices in 
society. Giroux (2015: 6) argues that transformative teachers safeguard and sustain critical thinking and engaged citizenship. When Giroux refers to criticality, he means that academics realise how processes of knowing and knowledge making are not equally open and accessible to everyone. Hence, a transformative intellectual identifies inequalities and makes learning and knowledge production accessible to all.

The propositions advanced by Giroux, et al. and Freire alert us to the university as a crucial institution where students' intellect is cultivated and developed, through stimulating intellectual insight, risk-taking and social responsibility. We argue that, while important, academics' worth should not be measured by their ability to produce work ready graduates at the expense of intellectual engagement. This became a critical consideration and cautioned us to the dangers of rigidly defining attributes (both for academics and students) in purely educational or econometric terms.

Bereiter and Scardamalia (2006) explore the question of what it means to be an educated person in the mid-21 ${ }^{\text {st }}$ century and what it means to survive in an 'innovation-driven' society, where yesterday's jobs are rapidly disappearing, as is becoming abundantly apparent in the context of the COVID-19 pandemic. Future jobs are entrepreneurial-technology-driven, and the new graduate can no longer rely on 'traditional academic knowledge'. Normative frameworks recognise that legitimate knowledge is derived from an evidential process. This compels the authors to acknowledge that a key professional attribute is the capacity to 'enculturate youth into this knowledge-creating civilization and to help them find a place in it' (ibid: 1). In the words of Bereiter and Scardamalia (2006: 3), a key attribute of a transformative intellectual is one who values the knowledge of generating knowledge collaboratively. An academic as intellectual is acutely aware of what knowledge is most worthwhile (Pinar, 2004; Pinar, 2016).

Fullan and Scott (2014) advocate what they refer to as the six Cs to include core attributes such as critical thinking, creativity, character education, citizenship, collaboration, and communication as relevant in curriculum design and the planning of educational contexts. Intelligent curriculum design is a core attribute for academics. To prepare for and survive in the technology-driven future where robots can replace human functions, the global citizen has the responsibility to distinguish himself/herself through attributes such as critical thinking. Other attributes linked to critical thinking are creativity, teamwork, communication skills and responsible citizenship, leading to an inquisitive, open-minded, systematic, analytic, 'truth-seeking', selfconfident, and mature citizen (Ennis, 1993; Hackworth, 2009). A critical thinker is thus equipped to operate across a range of occupational fields. However, the role of knowledge in developing critical thinking cannot be negated. One cannot think in the absence of knowledge. It is not only pedagogy that stimulates higher order thinking, but the very knowledge that needs to be acquired. Therefore, to facilitate knowledge transformation, Haggis (2006) argues in favour of pedagogical processes that challenge the diverse learning needs of the increasingly diverse student population.

Panettieni (2015) contends that the complexity of critical thinking creates barriers in teaching and assessing critical thinking. The barriers relate to the teachers' tendency to 'cover 
content' as they may themselves be insecure about the complexity of implementing critical thinking (Hackworth, 2009). Thus, time and resources can hinder the implementation of methodologies to teach and assess critical thinking. Students often lack motivation, confidence, and even prior knowledge to participate in class discussions to stimulate critical thinking. Additional barriers to learning that the transformative teacher can facilitate through the teaching process include bottlenecks (Middendorf and Shopkow, 2018) and threshold concepts (Cousin, 2006). Lending from Middendorf and Pace (2004), the teacher can assist the student to master specific disciplinary material, introduce the student to a culture of thinking and help to enter the specific discipline by facilitating in decoding the discipline. Although the authors do not subscribe to a neo-liberal agenda, the world of work need graduates who are critical thinkers and global citizens. This paper aims to identify the professional attributes of university teachers that would enhance this metamorphosis in the workplace.

\section{Approach and Methods}

This qualitative enquiry embedded in an exploratory, investigative paradigm, is comprised of six research projects as case studies. The six participants who were also the researchers, together with the group advisor, formed a research group of seven university teachers from seven different universities in South Africa, brought together in the 2018-2019 TAU Fellowship. Four participants are from traditional universities and three participants from universities of technology. The participants are from diverse disciplines, including theology, radiology, law and education and higher education while their advisor, an applied linguist, is a director of teaching and learning. The common denominator in the individual research projects was an enduring interest and concern with curriculum development and their own professional development through transformative learning in cultivating graduates as critical thinkers.

Over a period of three years, Fellows engaged in intense discussions and debates with each other and with other TAU Fellows, during the TAU Fellowship contact sessions and during presentations at various national and international seminars, workshops, and conferences. The ensuing critical-interdisciplinary conversations provided Fellows with the tools to make sense of their own SoTL endeavours, while developing an emerging typology of professional attributes amongst academics. Each author brought different critical perspectives allied to their own disciplines and professional dispositions, which enriched the 'critical conversations' and provided rich lenses to analyse the emerging insights (Pillay, in Dhunpath and Samuel, 2009: 35).

The group was able to generate the depth of analysis because their critical conversations transcended those in formal contact sessions. The reflective engagements were supplemented by online collaborations. Fellows were eager to critique each other's writings, mediated by their TAU advisor. These offered the opportunity for deep contemplation and debate. Additional data was drawn from the individual reflective reports and progress reports submitted to the advisor. The mind maps generated together with the field notes as well as a synthesis of respective SoTL perspectives, illuminated the Baobab metaphor and emergent rhizomatic thinking. 
The individual and group enquiry was undergirded by the SoTL principles propounded by Shulman (2002). The group was inspired by Shulman's ideas on educational outcomes and processes to be 'valued, e-valu-ated, and understood...for students and for teachers' (Shulman, 2015). Shulman distinguishes between 'Habits of Mind' - thinking analytically, reflectively, critically, intuitively, empathically; 'Habits of the Hand' - skill in methods, techniques, problemsolving strategies appropriate to areas of practical application and use, as well as the creative arts, both analytically and intuitively, planfully and improvisationally (sic), avoiding the excesses of methodolatry; and 'Habits of the Heart' - the personal and social meaning and identity formation; develop values, commitments, dispositions, affections, passions, motivations, a sense of self, of integrity, and of community (Shulman, 2015).

We now turn to some of the emerging insights which enabled participants to interrogate their praxis in defining what they considered professional attributes of academics as university teachers.

\section{Emerging Insights}

In this enquiry, a catalyst in exploring professional attributes was the Fellows' engagement with the notion of threshold concepts which students routinely encounter in their learning engagements. Meyer and Land (2003:1) describe threshold concepts as 'akin to a portal, opening up a new and previously inaccessible way of thinking about something. It represents a transformed way of understanding, or interpreting, or viewing something without which the learner cannot progress'. A threshold concept is essential for mastering the subject and for adopting the worldview of their graduate profession.

In the process of working on their own individual research projects, the group members identified thresholds in their own disciplines signalling the necessary attributes university teachers needed to help students break through those thresholds. It is helpful to understand the nature of these threshold concepts and how they are connected. Particular concepts need to be understood before a new concept can be grasped. The ability to systematically organise and sequence teaching and content in curriculum design, is an essential attribute of the university teacher.

This exercise underscored critical thinking as an inescapable attribute for a 'qualified' university graduate as well as for a university teacher. In addition, the range of familiar $21^{\text {st }}$ century skills such as creativity, communication, technology literacy, media literacy, flexibility, and collaboration recurred in all individual projects. While these are indeed familiar in our schemas as academics, their continued prevalence signalled the need to address them substantively. An emergent obligation, therefore, is to make these attributes explicit, as proposed in the DHET Framework. Mindful that an intellectual schema must move beyond frameworks which are limited to educational rhetoric, we explore in the section that follows, the six individual projects to demonstrate how the attributes were identified and affirmed. 
Researcher $A$ is a lecturer in the faculty of theology, whose research focuses on the graduate as a competent practitioner. He assigned himself the task of developing a competency framework for religious leadership to respond to his research finding - those students who graduated with ministerial practice, were found to possess a 'theoretical' knowledge base but were not in touch with the needs of the congregation. He defines competencies as 'a combination of cognitive, affective, motivational, volitional and social dispositions that form the basis for performance' (Shavelson, 2010: 43). Shavelson presents an approach to measuring and statistically modelling competency measurements by defining competency as a complex ability construct closely related to real-life-situated performance. The challenge is to make the construct 'competence' amenable to measurement in relation to its relevance for effective practice. Hence, competency-based theological education (CBTE) is the application of competency-based education in the field of theology, which according to the Association for Theological Schools (2018: 4), CBTE 'represents a paradigm shift in theological education. It offers an innovative way for seminaries and learning networks to raise a new generation of proven leaders, trained in context, in the knowledge, in the skills, and in the character traits they need to prosper in their callings' According to Brown (2016: 2), CBTE is 'an educational model that emphasizes: (1) learning more than 'seat time,' (2) the mastery of professionally-oriented competencies, (3) wellplanned learning activities or assessments (class-based or not, online or onsite) that students may complete at their own pace, and (4) a community of learning where regular and substantive interaction occurs between qualified faculty and students'.

Applying Giroux (1988) and Freire's (2000) conceptions of a transformed teacher and a transformative intellectual, it is reasonable to expect the lecturer to demonstrate these competencies himself/herself. In other words, the transformation that lecturers want to see in their students, should mirror their ontology. In becoming 'transformative intellectuals' teachers are in the position to engage in 'cultural hermeneutics'. In other words, reading socio-cultural contexts in which they teach, should enable them to develop critically relevant curricula that address the challenges posed by these contexts (Giroux, 1992), thus mirroring the principles of rhizomatic thinking. We argue that the transformed teacher would read the context to see how to best teach the competencies which have been privileged.

The emergent competency framework makes use of the insights of Barentsen (2016) but was integrated into the researcher's own frame of understanding (Nell, 2019). One of the purposes of a competency framework is to generate assessment strategies. The use of a competency framework can support in enhancing the acquisition of different practitioner skills, beyond members of the ministry. Through his deliberations with his project and the group, he was able to identify an engaged professional to catalyse creative knowledge generation as a core attribute for university teachers.

Researcher $B$ focused on a critical thinking taxonomy framework for radiography to determine how to provide the evidence of the required attributes, skills, and competencies. Critical thinking is seen as an important graduate attribute in radiography to facilitate clinical 
judgement and problem-solving (Pieterse, et al., 2016). In addition, critical thinking and problem solving are the skills linked to the 21 st century and the 4 th industrial revolution. A statement capturing critical thinking was used as a point of departure: A self-regulated radiographer/radiography student must apply professional knowledge, clinical experience, and ethical standards to interpret, analyse, evaluate, explain, and judge concepts and information for improved patient-centred care and healthcare outcomes (Gluyas, 2015). In this statement, professional knowledge refers to the cognitive domain, clinical experience relates to the psychomotor domain and clinical competence and lastly, ethical behaviour relates to the affective domain and metacognition. Like the rhizome, Morrow's (2009:39) analogy of the 'generative frame of the curriculum comes to mind and alludes to the ongoing learning and development of a radiography professional through continuous professional development.

Gosnell (2010) emphasises that critical thinking can be developed and scaffolded over time through a variety of pedagogies to stimulate deep learning approaches and higher order thinking. For this reason, critical thinking needs to be integrated and constructively aligned with the outcomes, teaching, learning and assessment activities and tasks. Recommended activities include interactive class discussions to stimulate debate and reasoning, case studies and problem-based learning and simulations. Through such a variety of teaching, learning and assessment tasks student/practitioners need to exhibit the desired attributes as essential requirements for the world of work. Practitioners need to role model these attributes in their teaching and assessment, mirrored by the constructs in Bloom's Taxonomy (Bloom, et al., 1956) such as: differentiate, contrast, argue, formulate, and investigate.

The identified domains of critical thinking of cognition, competence and metacognition were used to compile a framework as a helpful educational tool to provide evidence that practitioners can function at the required level and with the necessary attributes and competencies. From her quest to provide the evidence of the required attributes, skills, and competencies she identified her role as active learning mediator.

Researcher $C$ focused on the implementation of professional shadowing in the legal field by lecturers without practical experience in the legal world. She contends that a lecturer with the requisite theoretical disciplinary knowledge often lacks relevant current experience in practice, to engender practical knowledge in students. She therefore advocates mandatory industry shadowing by university teachers who have no exposure in the legal field. To fill this gap, she developed a draft policy to her university management. After presentations to all lecturers at the faculty board meetings of all faculties on campus and to the senate, the necessary 'buy-in' by management and academics was obtained, which made the policy easier to implement as consensus is an important part of curriculum development and innovation.

Industries and professional practices close to the university were coopted into the initiative. Lecturers placed themselves in appropriate workplaces. To assist some of the lecturers who could not find appropriate shadowing opportunities near the university or their place of residence, funding was obtained from the university's Centre for Academic Development. After a week of 
shadowing, the feedback obtained from lecturers was positive in all respects. Some of the lecturers noted that changes to the curriculum were necessary to include what they have observed during their shadowing and to prepare work-ready graduates. Similarly, industry/professional practitioners indicated that they welcomed this intervention as they expected a washback effect of students being sought after by employers upon graduation.

While it is true that this theory-practice nexus is now widely established, this was a tipping point for the university and lecturers who were able to experience the benefits of applied knowledge (Gibbons, 1994) to the advantage of students, when both students and lecturers were imbued with requisite practicum skills through collaborative learning, also characteristic of rhizomatic learning. After a year of implementing this initiative, these 'transformed' university teachers have moved beyond being skills practitioners to acquiring expertise as curriculum developers and have become valued assets to the university. What started out as an experiment, revealed the value of industry/practice shadowing by lecturers without experience which resonates with the group's espoused professional attributes of lecturers as responsive and innovative curriculum designers, and engaged professionals while being active learning mediators.

Researcher D embarked on a redesign of her current Bachelor of Law (LLB) Curriculum to enhance writing as a skill for law graduates. This project was necessitated by concerns about the writing skills of law students as identified in the national review of the LLB (CHE, 2017). In 2002, the Standards Generating Body for Legal Education and Training determined a set of exit level outcomes for the LLB degree, which were promulgated by the South African Qualifications Authority (SAQA) integrating skills and values into the degree outcomes. Exit-level outcomes that relate specifically to writing skills provide inter alia that 'learners who register for this qualification must ...possess or have sufficient potential to develop good communication skills, both orally and in writing' and that the 'learner is able to demonstrate adequate legal writing skills to operate in a wide variety of legal environments'. A decade later, the legal professions and the Law Society of South Africa (LSSA) raised concerns regarding the quality of the LLB and the lack of basic writing skills of law graduates.

As the curriculum redesign of the LLB curriculum (to promote essential graduate attributes including proficiency in reading, writing, comprehension, and speaking in a professional capacity) unfolded, it became apparent that analysis and evaluation of a curriculum requires the academic to have deep knowledge of curriculum design including the capacity to evaluate effectiveness and quality, the sensibility to identify strengths and weaknesses of the curriculum and the skill to imagine alternatives. It became increasingly clear that the 'received curriculum' designed by experts and adopted by practitioners was no longer defensible and that to be truly transformative, the recurriculated LLB should be reflective, responsive, and relevant to ensure flexibility within the curriculum.

It is patently obvious that the writing practices of students can only be enhanced if the academic has the necessary competencies and skills to adopt learning and teaching strategies 
that enhance the writing practices of students. However, central to the recurriculation project, is an awareness that a curriculum is more than the content being taught, as, like the rhizome, it extends to the purpose, environment, pedagogy, and applications of knowledge. Moreover, the outcome must be a framework that provides context and guidance beyond the pragmatic and instrumentalist concerns about content and placement of modules. For researcher D, this was a profound epiphany: what started out as an exercise in addressing writing proficiency and resulted in what Bereiter and Scardamalia (2006: 4) articulate as a realisation that

...knowledge building pedagogy is based on the premise that authentic creative knowledge work can take place in school classrooms-knowledge work that does not merely emulate the work of mature scholars or designers but that substantively advances the state of knowledge in the classroom community and situates it within the larger societal knowledge building effort.

While this project affirmed the previous researcher's proposition that a key attribute of a university teacher is being a responsive, relevant, and innovative curriculum designer, a key characteristic of rhizomatic thinking is affirmed: that transformative enquiry is necessarily generative where solutions to existing problems illuminate new problems with new solutions in upwardly spiralling possibilities for enhancement with no end in sight.

Researcher E another Law academic, focused on strengthening the promotion of desirable graduate attributes via the LLB curriculum through the design and inclusion of an active teaching and learning component in the degree. This project aimed to develop graduate attributes identified in the Council on Higher Education Annual Report (CHE, 2015) for LLB students through the design, creation, and production of short video clips in Corporate Law by small groups of students, role-playing scenarios from real-life corporate law.

This project was intended to be a continuous process of reflection and redesign. Once the initial discussions have been established, new knowledge will be used to adapt the curriculum, and a process will be designed to have an advisory team of experts in place to re-evaluate this on an annual basis. The expectations of the $\mathrm{CHE}$, the public, and practice regarding desirable law graduate attributes will be taken into account in conceptualising and designing interventions for use in the academic teaching and learning space to ensure that the relevant university teachers are equipped to provide students with the attributes required in practice (industry i.e., legal practice). Stakeholder involvement and support (academics, students, CHE, practitioners and, to some extent, the community) is crucial to developing the LLB curriculum by including learning components which achieve the desired objectives. The CHE LLB review has already identified that certain graduate attributes (and thus the competencies and skills required for cultivation of such graduate attributes) are not developed to the required standard in the existing LLB curriculum.

The video clip project produces hard evidence (an artefact) of a form of creative knowledge generation which may be evaluated externally. Further evaluation of the impact of the video clip 
project on teaching and learning and perceived development of skills and competencies underpinning the relevant graduate attributes can be obtained through student surveys. The skills and competencies (including creative knowledge generation and peer collaboration) that underpin the development of the desired graduate attributes of law students can only be developed and strengthened if the academic has the necessary competencies, skills, and tools to adopt transformative learning and teaching strategies that enhance these skills and competencies. The design and implementation of the video clip project is in essence an active learning component based on creative knowledge generation and intended to develop and strengthen selected LLB graduate attributes. If effective this design (or variations thereof) may be included in other curricula.

The creative knowledge generation within the module points to the attributes of a lecturer as being a responsive, innovative, and relevant curriculum designer, an engaged professional and an active learning mediator, displaying the key attributes of rhizomatic thinking.

Researcher $F$, a teacher educator, focused on the work-readiness of pre-service teachers of English. Based on a democratic curriculum development process, she attempted to align the expectations of the teaching profession and Department of Basic Education regarding the competencies and skills of a beginner teacher, with the expectations of the students and university lecturers. The overarching objective of the study was to investigate whether beginner teachers of English were prepared for a 'changing world' (Shulman and Shulman, 2004: 261), and what interventions to curriculum reform were necessary (if any) to link this knowledge to the relevant skills, attitudes, and activities in practice.

The project aimed to equip university teachers with the necessary skills and knowledge to develop the competencies of students for their future careers in teaching. University lecturers engage in responsive programme development to ensure that expectations of competencies and skills are aligned but questioned the extent to which the curriculum development process was seen as democratic and inclusive. Winberg, et al. (2017) point to concerns that have been expressed about student employability and graduate attributes in terms of the needs of the workplace. Allen (2009) argues that there has been an awareness of the theory-practice gap of beginner teachers, but that teacher educators have not been able to address this successfully. This is similar to findings by Sayed, et al. (2018) on Initial Teacher Training (ITE). Students are theoretically and technologically advanced but lack practical skills such as assessment, administration, and classroom management. The curriculum needs to be revised constantly to prepare beginner teachers for the current realities of the classroom.

Collaboration between all partners in preparing a competent graduate and beginner teacher requires inputs from lecturers, experienced teachers, departmental officials, subject advisors, previous students, and current students. According to Taylor (2016: 23) the quality of ITE will only be improved once teacher educators move their practices closer to those of practitioners (classroom teachers, principals, subject advisors) who are in the classrooms and 
schools themselves, and to be 'continuously interrogated by the practitioners themselves'. This implies a need for more collaboration among all university partners involved in education.

Curriculum design is dynamic, flexible, and never complete. Like the rhizome, this is a continuous process of reflection and redesign. Findings of the study will be used to adapt the curriculum and an advisory team of experts will be invited to re-evaluate this on an annual basis. University teachers can enhance lifelong learning and reflection by designing the curriculum collaboratively and ensuring relevance in the workplace. New knowledge is constantly being generated, and in a knowledge society a responsive curriculum is aligned to the latest developments in research and practice. The university academic no longer has the comfort of implementing a prescribed curriculum if she/he hopes to nurture students who are competent with the never-ending demands of the classroom. Teacher educators, like other academics in this study are pre-eminently responsive and Innovative curriculum designers while aspiring to be lifelong learners and transformative thinkers.

\section{Concluding observations}

This interdisciplinary project was conceived with the declared aim by seven academics to define graduate attributes of their students, which was later elevated to defining the professional attributes of university teachers to ameliorate the learning thresholds routinely encountered by their students. While this exercise affirmed the typology of graduate attributes in the extant literature, it served to ignite another compelling imperative: the need to identify relevant professional attributes of academics as university teachers. By applying their own lived experiences in their individual contexts, the academics as researchers embraced the metaphor of the Baobab tree with its rhizome-like root system which mirrored the branches and leaves, which is the original metaphor from which the emerging themes originated. Although a Baobab tree does not technically have a rhizomatic root system as such, its generative root system resembles what is sometimes called the 'upside-down' tree because, when bare of leaves, the spreading branches of the Baobab look like roots sticking up into the air, as if it had been planted upsidedown. This is a particularly revealing extension of the Baobab metaphor, as it illustrates the interconnectedness of academics as teachers with our students and the mutual influences university teachers exert as part of the whole: in effect the qualities, capabilities, and outputs of each are really reflections of the other. By the end of the TAU Fellowship sessions, the team concluded that, despite a potentially toxic climate in which the Baobab tree must live, it has the potential for growth and bearing fruit for the future as the roots are intertwined and resilient, yet flexible. This metaphor provides the lens to what lies beneath the surface, which is inextricably linked to the fruits of teachers' labour - the trunk, branches, leaves, flowers, and fruit, representing the University, students, and the communities in which they live and work. This organic ecosystem symbolises the simultaneous diversity and synchronicity of professional attributes necessary for 'developing contextually-responsive curricula that promote transformative values, attitudes and actions in higher education' (DHET, 2018). 


\section{Author Biographies}

Professor Rubby Dhunpath is the Director of Teaching \& Learning and Technology Enhanced Education at the University of KwaZulu - Natal (UKZN). A Fulbright Fellow, Rockefeller Fellow and Spencer Scholar, Rubby has researched and published in education policy, language policy, curriculum studies, and research methodology. His current interests include multidisciplinary higher education research, institutional research, and the scholarship of teaching \& learning.

Associate Professor Hesta Friedrich-Nel is the Assistant Dean: Teaching and Learning in the Faculty of Health and Environmental Sciences, Central University of Technology, Free State (CUT). A Fulbright scholar and TAU Fellow, Hesta's current research and publications is interdisciplinary and includes topics in Radiography, Radiation Therapy, Health Sciences Education, and the Scholarship of Teaching \& Learning.

Dr Lynn Biggs is a Senior Lecturer in the Faculty of Law, Nelson Mandela University. Her research focuses inter alia on Labour Law, Franchising Law and Legal Skills. Her involvement in the CHE National Review of the LLB curriculum in 2016 together with her TAU Fellowship 2018/2019 ignited further research interests in curriculum design and legal pedagogy.

Dr Hanlie Dippenaar is a senior lecturer in the Department of English, Faculty of Education, CPUT, Wellington. She holds a PhD from Northwest University. Her research interests are in Language Teaching, Community Engagement, Service-learning, and exploring Activity Theory and Change Laboratories.

Dr Deidre Joubert is a Senior Lecturer at Vaal University of Technology. She currently lectures Criminal-, Commercial-, and Corporate Law. By obtaining an additional ADHE qualification and participating in the TAU Fellowship (2018/2019), she developed a research interest in practicebased teaching and learning and online presentation of legal subjects.

Ian Nell is Professor of Practical Theology at the Faculty of Theology, Stellenbosch University. He teaches practical theology and ministry practice to undergraduate and post-graduate students. He coordinates the MDiv-program as well as the Post Graduate Diploma in Christian Ministry. His research focuses inter alia on leadership development and educational pedagogy.

Jacqueline Yeats is an Associate Professor in the Department of Commercial Law at the University of Cape Town. She teaches company law and corporate governance at postgraduate level, and has published widely in journals and books on these areas of law. Jacqueline's current research interests include commercial law, company law, corporate governance, and legal education. 


\section{References}

Allen, J.M. 2009. Valuing practice over theory: How beginning teachers re-orient their practice in the transition from the university to the workplace. Teaching and Teacher Education, 25(5): 647-654.

Aronowitz, S. \& Giroux, H. 1993. Education under Siege. Westport: Bergin \& Garvey.

Ashwin, P., Boud, D., Coate, K., Hallett, F., Keane, E., Krause, K.-L., Leibowitz, B., MacLaren, I., McArthur, J., McCune, V. \& Tooher, M. 2015. Reflective Teaching and Higher Education. London: Bloomsbury Academic.

Association for Theological Schools. 2018. Available at: https://www.ats.edu/uploads/accrediting/documents/guidelines-for-cbteprograms\%20\%2815\%20April\%202020\%29.pdf(Accessed: 14 December 2019)

Bereiter, C. \& Scardamalia, M. 2006. Education for the knowledge age: Design-centered models of teaching and instruction. In Alexander, P.A. \& Winne P.H. (eds.), Handbook of Educational Psychology. Mahwah: Lawrence Erlbaum Associates Publishers, 695-713.

Barentsen, J. 2016. Practising religious leadership. In Storey, J., Hartley, J., Denis, J.L., 't Hart, P. \& Ulrich, D. (eds.), Routledge Companion to Leadership. London: Routledge, 260-77.

Bloom, B.S., Engelhart, M.D., Furst, E.J., Hill, W.H. \& Krathwohl, D.R. 1956. Taxonomy of Educational Objectives: The Classification of Educational Goals. Handbook I: Cognitive Domain. New York: David McKay.

Brown, E.S. 2016. 'Time for Reset' in Theological Education: 200 Gather to Discuss Innovation at Education Models and Practices Forum. Available at: https://www.ats.edu/uploads/resources/publications-presentations/colloquy-online/edmodels-and-practices-forum.pdf. (Accessed: 10 January 2020)

CHE (Council on Higher Education). 2015. Annual Report. Available at https://firebasestorage.googleapis.com/v0/b/che2020c5efd.appspot.com/o/website\%2Fzo ylosuksne1?alt=media\&token=b63d1248-e37e-49a4-b5d8-74457fb5a860 (Accessed: 29 June 2020).

CHE (Council on Higher Education). 2017. National Review of the Bachelor of Laws (LLB) programme. Available from https://www.che.ac.za/sites/default/files/Final\%20reaccreditation\%20outcomes\%20of\%20the\%20Bachelor\%20of\%20Laws\%20(LLB)\%20National\%20 Review\%20as\%20of\%2007\%20June\%202018\%20\%20docx.pdf (Accessed: 29 June 2020)

Cousin, G. 2006. An introduction to Threshold Concepts Section 1: Introduction to threshold concepts. Planet no 17: 4-6.

Deleuze, G. \& Guattari, F. 1987. A Thousand Plateaus. Minneapolis: University Minnesota Press.

DHET (Department of Higher Education and Training). 2018. National Framework for Enhancing academics as University Teachers. Pretoria, South Africa: DHET.

Dhunpath, R. \& Samuel, M. (eds.) 2009. Life History Research: Ethics, Methodology, Representation. Rotterdam: Sense Publishers.

Ennis, R.H. 1993. Critical thinking assessment. Theory into Practice, 32(3): 179-186. 
Foucault, M. \& Gordon, C. 1980. Power/Knowledge: Selected Interviews and Other Writings, 1972-1977. New York: Pantheon Books.

Freire, P. 2000. Pedagogy of the Oppressed. $30^{\text {th }}$ ed. New York: Continuum.

Fullan, M. \& Scott, G. 2014. New Pedagogies for Deep Learning Whitepaper: Education PLUS. Seattle: Collaborative Impact SPC.

Gibbons, M.1994. The New Production of Knowledge: Dynamics of Science and Research in Contemporary Societies. London: Sage Publications Ltd.

Giroux, H. 1988. Teachers as Intellectuals: Toward a Critical Pedagogy of Learning. South Hadley, MA: Bergin \& Garvey.

Giroux, H. 1992. Border Crossings: Cultural Workers and the Politics of Education. New York: Routledge.

Giroux, H. 2015. Neoliberalism's war against higher education and the role of public intellectuals. Límite Revista Interdisciplinaria de Filosofía y Psicología, 10(34): 5-16

Giroux, H.A. 2003. Public pedagogy and politics of resistance: Notes on a critical theory of educational struggle. Educational Philosophy and Theory, 35(1):5-16.

Giroux, H.A. \& McLaren, P.L. 1989. Critical Pedagogy, the State and Cultural Struggle. New York: SUNY Press.

Gluyas, H. 2015. Patient-centred care: improving healthcare outcomes. Nursing Standard, 30(4): 5059. DOI: $10.7748 / \mathrm{ns} .30 .4 .50 . e 10186$.

Gosnell, S. 2010. Teaching and Assessing Critical Thinking in Radiologic Technology Students. Unpublished D Ed dissertation, University of Central Florida, USA.

Hackworth, R.M. 2009. Radiation Science Educators' Perception of Obstacles in the Use of Critical Thinking. Unpublished PhD Dissertation, Ohio State university, USA.

Haggis, T. 2006. Pedagogies for diversity: retaining critical challenge amidst fears of 'dumbing down'. Studies in Higher Education, 31(5): 521-535.

Harland, T. 2003. Vygotsky's zone of proximal development and problem-based learning: Linking a theoretical concept with practice through action research. Teaching in Higher Education, 8(2): 263-272.

Kincheloe, J.L., Mclaren, P. \& Steinberg, S.R. 2018. Series Editors' foreword. In H. Giroux, H. (ed.) Pedagogy and the Politics of Hope: Theory, Culture and Schooling. New York: Routledge, ix-xii.

Meyer, J. \& Land, R. 2003. Threshold Concepts and Troublesome Knowledge: Linkages to Ways of Thinking and Practising within the Disciplines. Edinburgh: University of Edinburgh.

Mezirow, J. 2009. An overview on transformative learning. In Illeris, K. (ed.) Contemporary Theories of Learning. Learning Theorists ... in their own Words. London: Routledge: 90-105.

Middendorf, J. \& Pace, D. 2004. Decoding the disciplines: A model for helping student learn disciplinary ways of thinking. New Directions for Teaching and Learning, 98: 1-12.

Middendorf, J. \& Shopkow, L. 2018. Overcoming Student Learning Bottlenecks: Decode the Critical Thinking of your Discipline. 1st ed. Virginia: Stylus Publishing.

Morrow, W. 2009. Bounds of Democracy: Epistemological Access in Higher Education. Cape Town: Human Science Research Council. 
Nell, I.A. 2019. Post-colonial leadership? The challenges facing a new generation of theologians. Lecture delivered at the opening of the Academic Year of the Protestant Theological University on the 2nd of September 2019, Vrijburg Gemeente, Amsterdam. https://www.pthu.nl/actueel/agenda/ian-nell-postcolonial-leadership.pdf

Northedge, A. 2003. Enabling participation in academic discourse. Teaching in Higher Education, 8(2): 169-180.

Panettieni, R.C. 2015. Can critical thinking skills be taught? Radiologic Technology, 86(6): 686 688.

Pieterse, T., Lawrence, H. \& Friedrich-Nel, H. 2016. Critical thinking ability of $3^{\text {rd }}$ year radiography students. Health SA Gesondheid, 21(1): 381-390.

Pinar W. 2016. What knowledge is of most worth? In: Samuel, M.A., Dhunpath, R. \& Amin, N. (eds.) Disrupting Higher Education Curriculum. Constructing Knowledge: Curriculum Studies in Action. SensePublishers, Rotterdam.

Pinar, W.F. 2004. What is Curriculum Theory? New York: Routledge?

Shavelson, R.J. 2010. On the Measurement of Competency. Empirical Research in Vocational Education and Training, 2(1): 41-63.

Sayed, Y., Carrim, N., Badroodien, A., McDonald, Z. \& Singh, M. 2018. Learning to teach in postapartheid South Africa: student teachers' encounters with Initial Teacher Education. Stellenbosch: African Sun Media.

Shulman, L.S. 2002. Foreword. In Hutchings, P. (ed.). Ethics of inquiry: Issues in the Scholarship of Teaching and Learning. Stanford: Carnegie Foundation for the Advancement of Teaching.

Shulman, L.S. 2015. Between Research and Practice: Situating a scholarship of teaching and learning within the professional, intellectual and moral landscape of the Academy, Annual Teaching and Learning Conference, Durban, South Africa. 2015.

Shulman, L.S. \& Shulman, J.H. 2004. How and what teachers learn: A shifting perspective. Journal of Curriculum Studies, 36(2): 257-271.

Taylor, N. 2016. Thinking, language and learning in initial teacher education. Perspectives in Education, 34(1): 10-26.

Trowler, P. 2005. Academic tribes: their significance in enhancement processes. Proceedings of Utvecklingskonferensen 2005 i Karlstad.

Wheelahan, L. \& Moodie, G. 2021. Gig qualifications for the gig economy: micro-credentials and the 'hungry mile'. Higher Education. https://doi.org/10.1007/s10734-021-00742-3

Winberg, C., Staak, A., Bester, M., Scholtz, D., Sabata, S., Monnapula-Mapesela, M., Sebolao, R.,Ronald, N., Makua, M., Snyman, J. \& Machika, P. 2017. In search of graduate attributes: A survey of six flagship programmes. South African Journal of Higher Education, 32(1): 1-19. 